\title{
Empirical Verification of Dynamic Dependences Between Productivity and Economy Openness. The Case of Visegrad Countries
}

\begin{abstract}
This study analyses one of the main postulates of the Endogenous Growth Theory, that suggests that international trade openness is capable to speed up growth-impacting productivity. ADF stationary tests, Johansen co-integration test and Vector Error Correction Model (VECM) procedures are applied on a yearly data set covering the period 1995-2014. Data for individual V4 countries were also compared with EU-15 benchmark. The main finding of the paper is that for all V4 countries there exists a long term relationship between economy openness and labour productivity and in case of Hungarian economy in the Granger sense - causality is one-directional and runs only from productivity to openness. It suggest, that the Endogenous Growth Theory in this case is no longer supported nevertheless further and deeper investigation is needed. Although huge differences in case of openness between V4 countries exist, strong positive linear correlation with productivity is observed. Also disturbing secondary result of conducted research is that however convergence in case of productivity between V4 and EU-15 is observed, assuming the current rate of catching-up (apart from existence of saturation level of productivity), EU-15 and V4 average productivity would equal in 6 decades.
\end{abstract}

Keywords: co-integration; market openness; productivity; stationary; VECM

Received: 10 November 2015

Accepted: 22 February 2016

\section{Suggested citation:}

Wojciechowski, L. (2015). Empirical verification of dynamic dependences between productivity and economy openness. The case of Visegrad Countries. Przedsiębiorczość - Edukacja [Entrepreneurship - Education], 12, 149-161.

\section{Introduction}

Endogenous growth theory assumes that economic growth is primarily the result of endogenous and not external forces (Romer, 1994). Endogenous growth theory holds also that investment in innovation, human capital are significant contributors to economic growth. The theory also focuses on positive externalities and spillover effects of a knowledge-based economy which will lead to economic development. The endogenous growth theory primarily holds that the long-run growth rate of an economy depends on policy measures. Romer (1986), 
Lucas (1988), Rebelo (1991) omitted the technological change - instead, growth in these models is due to indefinite investment in human capital which has a spillover effect on economy and reduces the diminishing return to capital accumulation (Barro, Sala-i-Martin, 2004). One of the main failings of endogenous growth theories is the collective failure to explain conditional convergence reported in the empirical literature (Sachs, Warner, 1997). Parente (2001) affirms that new growth theory has proven to be no more successful than exogenous growth theory in explaining the income divergence between the developing and developed. Krugman (2013) criticized endogenous growth theory as nearly impossible to empirically verify.

Taking into account the on-going globalization processes and dynamically changing conditions in international environment, the relationship between openness to trade and economic growth has been of continuing interest both in theoretical and empirical grounds. The endogenous growth theory does not argue that trade increases economic growth rate, rather it suggests that trade may open up several channels thorough which productive agents become more capable, consequently increasing growth rate. Therefore, in order for an economy to achieve higher growth rates by trading, these channels should be working favourably on behalf of the country's productive means (Gunes, Kose, 2013: 72). According to Cameron et al. (1998), major possible channels may be due to:

- "see-how" transfers, the stimulation of the adaptation of new foreign technological advances,

- the acceleration of specialization and efficacy, and thus, spurring international competition,

- the generation of larger economies of scale in production, which in turn encourages research and development (R\&D) activities.

In economics, total-factor productivity (TFP) is a variable which accounts for effects in total output growth relative to the growth in traditionally measured inputs of labour and capital. If all inputs are accounted for, then total factor productivity (TFP) can be taken as a measure of an economy's long-term technological change or technological dynamism. This variable cannot be measured directly so it has to be estimated by using appropriate model of growth, i.e. Cobb-Douglas equation or CES function. Taking into account the C-B equation (1), where total output $Y$ is a function of TFP $A$, capital input $C$, and labour input $L$, and it shares represented by parameters $\alpha$ and $\beta$.

$$
Y=A \times C^{\alpha} \times L^{\beta}
$$

According to Easterly and Levine (2001), TFP may account for up to $60 \%$ of growth within economies. TFP can be measured more accurately in long term, since TFP can vary substantially from one year to another (Machek, 2012).

The idea that trade openness breeds productivity growth has been expressed by many researchers. In case of China there is significant evidence that productivity growth in the tradable sector is co-integrated with openness and there is some supporting evidence that the increase in competition in the domestic market is an important channel through which openness breeds productivity growth as well (Yan, Chong, Kwok, 2007). In case of Indian Economy, Saha (2012) examined dependences between TFP growth and economy openness and found out that economy has been experiencing continuous rise in TFP growth since the introduction of external economic reforms. Granger Causality tests showed that there is a one way relationship between trade openness and TFP growth for Indian economy, that suggest 
more outward oriented policies would further in enhancing the productivity of the economy. However, existing studies throw mixed picture regarding the impact of openness on the TFP of different countries. Lee (2007) and Xu et al. (2008) observed positive and insignificant relationship between trade openness and TFP for Chinese economy. Indonesia, Malaysia, Thailand and South Korea were influenced negatively and significantly for two decades. Gonzalez and Constantin (2009) also found that openness is not a very relevant factor in explaining the role of technological status of the low income countries. On the contrary, openness affects TFP positively and significantly for middle and high income countries. Kumar et al. (2010) have examined the impact of trade openness on TFP of South Africa and observed that it affects TFP positively and significantly.

The empirical literature on trade and productivity or growth mostly uses the basic measure of openness, which is a sum of exports and imports divided by GDP. The methodological orientation of the literature, however, varies greatly. Mentioning some, Sachs and Warner (1995), and Edwards (1998) employ cross-section analysis, Yanikkaya (2003) utilizes panel-data regressions, Tsen (2006) uses time series techniques. Many studies find a positive and statistically significant relationship between openness to trade and growth or productivity. For example, Barro (2001), using data for about 100 countries, finds that on average, calculated for a 10-year period, openness increases the growth rate of real per capita GDP by 13 per cent. In a similar study mentioned above Yanikkaya (2003) estimates it being about 2 percent for a year.

Herzer (2005) assumed, however, that many of the cross-country specifications suffer from methodological problems such as heterogeneity, error autocorrelation and simultaneity bias. Therefore, the robustness of specific results of many of these types of studies, which constitute vast majority of the related literature, is dubious. However, Rodriguez and Rodrik (1999) had argued that the empirical research did not provide convincing evidence, considering positive openness-growth nexus.

In this study we consider another measure of productivity: real labour productivity, in contrast to most of researches that estimates model explaining gross value added per employee or TFP in literature bearing to compare results. One of the objectives is to compare is to check to what extent the use of this variable is justified and whether it is possible to obtain meaningful conclusions.

The methodical issues presented in many studies estimating the considering relationship are still inconclusive. In order to avoid most of the methodological setbacks mentioned, in this study the Vector Error Correction Model (VECM) procedures are utilized to determine the possible relationship between openness to trade and labour productivity. Cross-country analysis is provided while we consider the countries separately.

The rest of the study is structured as follows. Section 2 describes the objectives, hypothesis and data. Section 3 covers methodological issues. Section 4 throws light on the results and discussion. Section 5 concludes the study.

\section{Data and hypotheses}

Our yearly data includes openness to trade (2) (Openness) and labour productivity (3) (Productivity). The variable Openness is the sum of exports and imports of goods and services (in current prices) as a share of gross domestic product. The productivity variable we use is the 
real labour productivity per hour worked denominated in euro. Time series for both variables were obtained from the EUROSTAT database, and cover the period of 1995-2014. ${ }^{1}$

$$
\begin{gathered}
\text { Openness }=\frac{\text { exports of goods and services }+ \text { imports of goods and services }}{\text { Gross Domestic Product }} \times 100 \\
\text { Productivity }=\frac{\text { real labour productivity }[\text { eur }]}{\text { hours worked }}
\end{gathered}
$$

The Figure 1 below shows the behaviours of Openness of V4 and EU-15 countries, covering the period of 1995-2014. In the mid-90s the greatest level of openness is observed in case of Slovakia. Sum of exports and imports of goods and services exceeds GDP. In cases of Hungary and Czech Republic it accounted for a large part (84.3 and 78.5 per cent respectively) and in Poland only 43.7 per cent, which was the closest to EU-15 average (54.2 per cent). Comparing years 2014 and 1995 we find that Openness increased by only 47 per cent in case of EU-15 countries and 61 per cent for Slovakia. Hungary became an extremely large (comparable to Slovakia) economy, gaining 123 per cent in case of sum of exports and imports to GDP ratio.

Figure 1: Openness of economy in V4 and EU-15 countries in the years 1995-2014

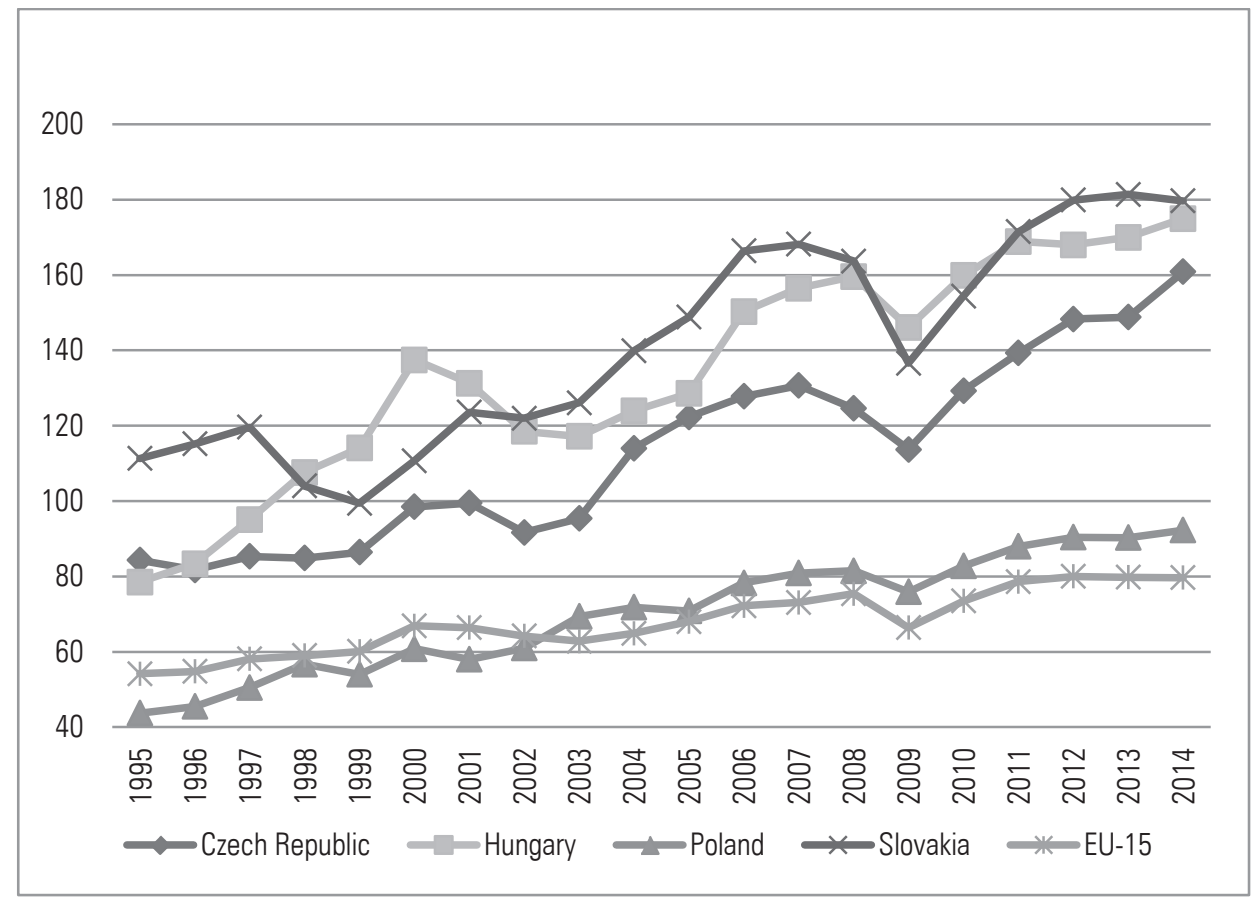

Source: Eurostat

\footnotetext{
${ }^{1}$ There were no data for productivity for the year 2014 and for this year for all countries naïve forecasts with increment were calculated. In case of Poland Eurostat presents productivity value of 13.2 for the year 1999, what we assumed is abnormal outlier, so we put average for the years 1998 and 2000 , which is $9.45 \mathrm{EUR} / \mathrm{h}$.
} 
Generally, it can be said that economies are becoming more and more open, especially small ones like Czech Republic, Slovakia and Hungary, however if we focus on dynamics of Openness it is clear that the average rate of growth of this ratio for EU-15 countries was only 2.05 per cent yearly, whereas in Poland, Slovakia and Hungary it was over 4.3 per cent, and nearly 3.5 per cent in case of Czech Republic.

Figure 2 shows how great differences there are still between productivity in the V4 Group and the old EU countries. In the end of the 1990s, an average productivity in V4 was nearly 4.4 lower than in EU-15. 20 years later, in 2014 productivity in EU-15 was more than 3 times higher than in Poland, Czech Republic, Slovakia and Hungary on average. It is also important to mention significant differences between individuals in V4 (13.6 EUR/h in Slovakia and 10.8 EUR/h in Poland in 2014). Although huge differences in case of openness between V4 countries exist, strong positive linear correlation with productivity is observed. The most disturbing fact is that however convergence in case of productivity between V4 and EU-15 is observed, assuming the current rate of productivity growth (apart from the assumption of productivity saturation level), it would take almost 6 decades to catch up with old EU Member States in sense of productivity level, and also wealth.

Figure 2: Real productivity of labour in V4 and EU-15 countries in EUR in the years 1995-2014

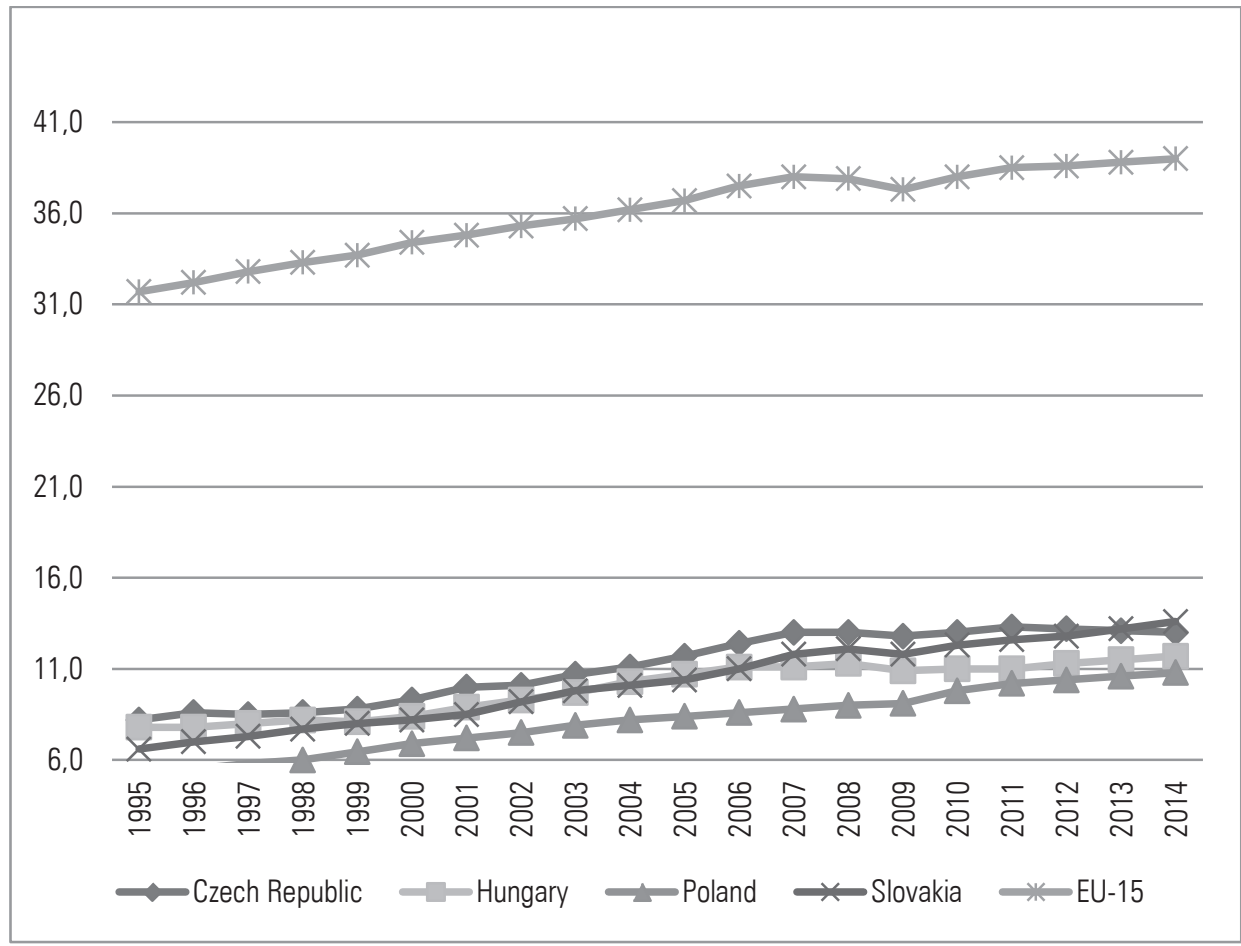

Source: Eurostat

In this paper we verify, using econometric methods hypothesis, states that economy openness in terms of (exports + imports)/GDP leads to more productive economy in terms of real productivity per employee in EUR. 


\section{Methodology}

The study begins with an analysis of the correlation between Productivity and Openness in V4 and EU-15 countries. In order to determine whether, and if so, what is the direction of the interaction between variables, the analysis of Granger causality (Granger, 1969: 424) using stationary rates of return (Dickey \& Fuller, 1979: 427-431) was checked. This was followed by estimating the VECM (Kusideł, 2000: 27-34) to determine whether there are compounds having a long-term effect variables. We use the methodology proposed by Johansen (Johansen, 1988: 231-254) in order to identify the co-integrating relationship. In case when two or more time-series share a common stochastic trend, there occurs a suspicion of co-integration existence. Co-integration is defined when the error term in the regression modeling is stationary. The Johansen test is a test for co-integration that allows for more than one co-integrating relationship, unlike the Engle-Granger (1987) method, but this test is subject to asymptotic properties, i.e. large samples. All calculations were conducted in JMulti.

\section{Results and Discussion}

Although huge differences in case of openness between the V4 countries exist, strong positive linear correlation with productivity is observed (Table 1).

Pearson's coefficient of linear correlation as well as Figures above suggest that variables are moving in consistent trends, which is a prerequisite for testing co-integration and VECM estimation.

Table 1. Pearson's coefficients of linear correlation between variables, $\mathrm{T}=20$ (1995-2014)

\begin{tabular}{|r|l|c|c|c|c|c|c|c|c|c|c|}
\cline { 2 - 13 } \multicolumn{1}{|c|}{ Variable } & {$[\mathbf{1}]$} & {$[2]$} & {$[3]$} & {$[4]$} & {$[5]$} & {$[6]$} & {$[7]$} & {$[8]$} & {$[9]$} & {$[\mathbf{1 0}]$} \\
\hline$[1]$ & Openness UE-15 & 1.00 & & & & & & & & & \\
\hline$[2]$ & Productivity UE-15 & 0.95 & 1.00 & & & & & & & & \\
\hline$[3]$ & $\begin{array}{l}\text { Openness Czech } \\
\text { Republic }\end{array}$ & 0.95 & 0.94 & 1.00 & & & & & & & \\
\hline$[4]$ & $\begin{array}{l}\text { Productivity Czech } \\
\text { Republic }\end{array}$ & 0.91 & 0.98 & 0.92 & 1.00 & & & & & & \\
\hline$[5]$ & Openness Hungary & 0.98 & 0.96 & 0.92 & 0.92 & 1.00 & & & & & \\
\hline$[6]$ & Productivity Hungary & 0.90 & 0.98 & 0.93 & 0.98 & 0.90 & 1.00 & & & & \\
\hline$[7]$ & Openness Poland & 0.96 & 0.99 & 0.96 & 0.96 & 0.95 & 0.96 & 1.00 & & & \\
\hline$[8]$ & Productivity Poland & 0.95 & 0.98 & 0.95 & 0.96 & 0.95 & 0.95 & 0.98 & 1.00 & & \\
\hline$[9]$ & Openness Slovakia & 0.92 & 0.92 & 0.96 & 0.93 & 0.86 & 0.93 & 0.93 & 0.91 & 1.00 & \\
\hline$[10]$ & Productivity Slovakia & 0.94 & 0.99 & 0.95 & 0.98 & 0.94 & 0.97 & 0.99 & 0.99 & 0.93 & 1.00 \\
\hline
\end{tabular}

Source: own study

Before the estimation of long run relationship models, a degree of integration of particular time series (in natural logarithms and first-differenced natural logarithms - rates of 
Table 2. ADF Unit Root Test Results

\begin{tabular}{|c|c|c|c|c|c|c|c|c|c|}
\hline \multirow[t]{2}{*}{ Item } & \multirow[t]{2}{*}{ Statistics } & $\begin{array}{c}\text { No } \\
\text { trend }\end{array}$ & $\begin{array}{l}\text { Linear } \\
\text { Trend }\end{array}$ & $\begin{array}{c}\text { No } \\
\text { trend }\end{array}$ & $\begin{array}{l}\text { Linear } \\
\text { Trend }\end{array}$ & 1995 & 2014 & 1995 & 2014 \\
\hline & & \multicolumn{2}{|c|}{ InProductivity } & \multicolumn{2}{|c|}{ lnOpenness } & \multicolumn{2}{|c|}{ Productivity } & \multicolumn{2}{|c|}{ Openness } \\
\hline \multirow{5}{*}{ EU-15 } & ADF stat & -2.103 & -0.65 & -0.929 & -3.719 & \multirow{5}{*}{31.7} & \multirow{5}{*}{39} & \multirow{5}{*}{54.2} & \multirow{5}{*}{79.7} \\
\hline & p-value & 0.244 & 0.976 & 0.78 & 0.021 & & & & \\
\hline & & \multicolumn{2}{|c|}{ d_lnProductivity } & \multicolumn{2}{|c|}{ d_lnOpenness } & & & & \\
\hline & ADF stat & 0.241 & 0.024 & -3.759 & -3.65 & & & & \\
\hline & p-value & 0.975 & 0.997 & 0.003 & 0.026 & & & & \\
\hline \multirow{6}{*}{$\begin{array}{l}\text { Czech } \\
\text { Republic }\end{array}$} & & \multicolumn{2}{|c|}{ lnProductivity } & \multicolumn{2}{|c|}{ InOpenness } & \multirow{6}{*}{8.2} & \multirow{6}{*}{13} & \multirow{6}{*}{84.3} & \multirow{6}{*}{160.9} \\
\hline & ADF stat & -1.207 & -0.146 & -0.18 & -1.423 & & & & \\
\hline & $\mathrm{p}$-value & 0.674 & 0.994 & 0.939 & 0.855 & & & & \\
\hline & & d_lnPro & luctivity & d_lnO & enness & & & & \\
\hline & \multirow{2}{*}{$\begin{array}{l}\text { ADF stat } \\
\text { p-value }\end{array}$} & -0.405 & -2.594 & -4.032 & -4.099 & & & & \\
\hline & & 0.906 & 0.283 & 0.008 & 0.001 & & & & \\
\hline \multirow{6}{*}{ Hungary } & \multirow{4}{*}{$\begin{array}{l}\text { ADF stat } \\
\text { p-value }\end{array}$} & \multicolumn{2}{|c|}{ lnProductivity } & \multicolumn{2}{|c|}{ lnOpenness } & & & & \\
\hline & & -1.434 & -1.262 & -1.302 & -3.441 & \multirow{5}{*}{7.8} & \multirow{5}{*}{11.7} & & \\
\hline & & 0.567 & 0.897 & 0.631 & 0.046 & & & & \\
\hline & & \multicolumn{2}{|c|}{ d_lnProductivity } & \multicolumn{2}{|c|}{ d_lnOpenness } & & & 78.5 & 175 \\
\hline & ADF stat & -1.638 & -1.817 & -2.921 & -2.894 & & & & \\
\hline & $\mathrm{p}$-value & 0.463 & 0.697 & 0.156 & 0.046 & & & & \\
\hline & & $\ln$ Prod & Ictivity & $\operatorname{lnOp}$ & nness & & & & \\
\hline & ADF stat & -2.261 & -1.435 & -2.01 & -0.992 & & & & \\
\hline Poland & p-value & 0.185 & 0.851 & 0.283 & 0.944 & & & & \\
\hline roland & & d_lnPro & luctivity & d_lnO & enness & 5.2 & 10.8 & 43.7 & 92.3 \\
\hline & ADF stat & -2.214 & -3.179 & -4.09 & -4.557 & & & & \\
\hline & $\mathrm{p}$-value & 0.202 & 0.089 & 0.001 & 0.001 & & & & \\
\hline & & $\ln$ Prod & ictivity & $\operatorname{lnOp}$ & nness & & & & \\
\hline & ADF stat & -1.471 & -0.218 & -0.375 & -3.33 & & & & \\
\hline Sloulrio & p-value & 0.549 & 0.993 & 0.911 & 0.061 & & & & \\
\hline sıovakia & & d_lnPro & luctivity & d_lnO & enness & 6.6 & 13.6 & 111.3 & 179.7 \\
\hline & ADF stat & -0.713 & 0.123 & -3.647 & -3.571 & & & & \\
\hline & & 0.842 & 0.998 & 0.005 & 0.032 & & & & \\
\hline
\end{tabular}

Using Schwert formula for choosing number of lags we put lag=7 for differenced logarithms and 8 for non-differenced. Bolded p-values are less than level of significance $-10 \%$.

Source: own study in JMulti 
growth) should be examined using $\mathrm{ADF}^{2}$ stationary test. Many macroeconomic series appear to be rather non-stationary. The augmented Dickey-Fuller (1981) testing procedure is applied in the study. In null hypothesis it is assumed that the unit-root in time series exist, so it is non-stationary. The results of the ADF unit root tests for logs and first-differences of logs are presented in Table 2. Table also contains a comparison of Productivity and Openness levels in years 1995 and 2014 for individuals.

In Table 2 the ADF unit root test results show that in case of Productivity time series are not stationary (as well as their differences, which is quite a rare occurrence, but probably connected with the fact that there is lack of observations $\mathrm{T}=20$ ). Only in case of Poland, if we assume that $d \_$InProductivity is stationary For EU-15 we observe non stationary logarithms of Productivity and Openness (without trend) and stationary rates of growth of Openness in both ADF test versions. For Czech-Republic only rates of growth of Openness are stationary according to ADF test (without and with trend). The results show that in all cases of ADF Unit Root Test for logarithms, ADF statistics confirm that logs of Openness variable are non-stationary, however in some cases even first differences in log terms are still not. Generally, Productivity and Openness are I(1) in case of Poland. In case of Hungary we observe that logarithms of Openness as well as rates of growth are stationary only in case with linear trend in ADF test formula. For Poland we cannot reject the null hypothesis in ADF test for logarithms of Productivity and Openness, but in case of increases of logarithms, particularly for Openness we can. Utilizing ADF-GLS (1992) and KPSS (1992) accepting 10\% level of significance, considered variables are stationary in their first differences. In case of Slovakia we can assume that logarithms of Openness and Productivity are non-stationary on the 0.05 significance level, however we can reject null hypothesis only for increases of logarithms for Openness. taking into account linear trend we reject null hypothesis with high risk of 0.1 .

As we have confirmed the existence of unit roots for considered time series, in the next step we can apply test for co-integration to detect possible long-run equilibrium relationship. The Johansen testing procedure uses two test statistics (trace and maximum eigenvalue) to determine the number of co-integrating vectors. When using $\lambda_{\text {trace }}=T \sum_{j=r+1}, n \ln \left(1-\lambda_{j}\right)$ relationship, the trace test statistic for the null hypothesizes that there are at most $r$ number of co-integrating vectors. In the equation $T$ represents the number of observations in the series, and $\lambda_{j}$ s shows the estimated values of the characteristic roots, assuming that the series are I(1). Then, the use of $\lambda_{\max }=-T \ln \left(1-\lambda_{r+1}\right)$ equation provides the maximum eigenvalue test statistic, for which the null hypothesis is there are at most $r$ number of co-integrating vectors, and the alternative hypothesis is there are $r+1$ co-integrating vectors.

Taking into account the obtained results for ADF test we expect that there could exist a long-run relationship between non-stationary logarithms for ln_Productivity and ln_Openness for EU-15 and the same for Czech Republic and Poland (Table 2). Analysing data from (Table 2) and comparing with (Table 3), it seems to be concerning whether it could be possible to estimate the VECM models for all countries, however we expect at least one-way causality in equation systems for Slovakia and Hungary. The Author is aware that one of the reasons that Johansen and ADF tests do not give fully conclusive results is lack of number of observations. Nevertheless, we try to estimate VECM models relying in part on the informal methods, among others the time series graphs analysis.

2 ADF test $\Delta y_{t}=\alpha+\gamma t+\pi y_{t-1}+\sum_{i=1}^{k} \gamma_{i} \Delta y_{t-1}+v_{t}$ where $y_{-}$tis the individual series of interest, $\Delta$ is the first difference operator, $\mathrm{t}$ is a linear time trend and $k$ is determined by Akaike's information criterion (AIC) to determine that $v_{-} t$ is white noise. 
Table 3. The Johansen co-integration test results

\begin{tabular}{|l|c|c|c|c|c|c|}
\hline \multicolumn{1}{|c|}{ Item } & Lag & Eigenvalues & Trace test & p-value & Lmax test & p-value \\
\hline \multirow{2}{*}{ EU-15 } & 0 & 0.415 & 16.651 & $\mathbf{0 . 0 3 2}$ & 10.178 & 0.204 \\
\cline { 2 - 7 } & 1 & 0.289 & 6.473 & $\mathbf{0 . 0 1 1}$ & 6.473 & $\mathbf{0 . 0 1 1}$ \\
\hline \multirow{2}{*}{$\begin{array}{l}\text { Czech } \\
\text { Republic }\end{array}$} & 0 & 0.200 & 5.738 & 0.728 & 4.234 & 0.829 \\
\cline { 2 - 7 } & 1 & 0.076 & 1.504 & 0.220 & 1.504 & 0.220 \\
\hline \multirow{2}{*}{ Hungary } & 0 & 0.269 & 7.812 & 0.493 & 5.960 & 0.624 \\
\cline { 2 - 7 } & 1 & 0.093 & 1.852 & 0.174 & 1.852 & 0.174 \\
\hline \multirow{2}{*}{ Poland } & 0 & 0.577 & 22.168 & $\mathbf{0 . 0 0 4}$ & 16.362 & 0.021 \\
\cline { 2 - 7 } & 1 & 0.263 & 5.806 & $\mathbf{0 . 0 1 6}$ & 5.806 & $\mathbf{0 . 0 1 6}$ \\
\hline \multirow{2}{*}{ Slovakia } & 0 & 0.433 & 12.888 & 0.119 & 10.792 & 0.167 \\
\cline { 2 - 7 } & 1 & 0.104 & 2.096 & 0.148 & 2.096 & 0.148 \\
\hline
\end{tabular}

Lag lengths are selected according to the AIC, no restrictions on the constat term are imposed (only for UE-15 and Czech Republic restricted trend was also imposed), basing on natural logarithms of variables.

Source: own study in JMulti

Basing on the results of trace statistics co-integrating relation on time series for EU-15 and Poland are observed. In other cases tests do not give a clear answer, nevertheless we decided to estimate Vector Error Correction Models for all cases. This finding shows that there is a longrun relationship between productivity and openness. In their fundamental research, Engle and Granger (Granger, 1983; Engle, Granger, 1987) illustrated that the co-integrating series must have an error correction model (ECM) representation.

$\Delta$ lnProductivity $_{t}=\gamma+\sum \theta(i) \Delta$ lnOpenness $_{t-i}+\sum \Phi(i) \Delta \ln$ Productivity $_{t-i}+\psi E_{t-1}+v_{1 t}[4]$

$\Delta$ lnOpenness $_{t}=\alpha+\sum \delta(i) \Delta$ lnProductivity $_{t-i}+\sum \Gamma(i) \Delta$ LlnOpenness Pr-i $_{t}+\varphi E_{t-1}+v_{2 t}$

Introducing equations (3) and (4) above, $\Delta$ is called first-difference operator, $v_{1 t} v_{2 t}$ are white noise residuals, and $\gamma, \theta, \Phi, \psi, \alpha, \delta, \Gamma$ and $\phi$ are parameters to be estimated. If we let $\Lambda$ represent $\theta, \Phi, \delta$, and $\Gamma$ then $\Lambda m n, i$ shows the effect of the $i$-th lagged value of variable $n$ on the current value of variable $m$. Et-1 represents the error correction term. This term gives residuals from co-integration regression

In the VECM model, the coefficients of $E_{t-1}, \psi$ and $\phi$, possess the adjustments of InProduc-

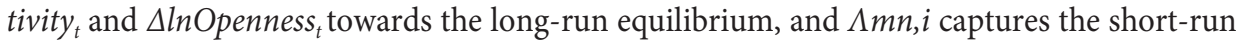
dynamics of the given model. The vector error correction model (VECM) estimation results obtained from equations (4) and (5) for EU-15 and four individual V4 countries are given in Table 4 below:

One lag for all equations were the best fitting specifications, taking into account AIC criterions. From Table 4 we can see that there is a unidirectional Granger-causality in the model, because only $\varphi$ is significant and the other long run impact parameter $\psi$ is not. Unexpectedly the causality runs from productivity to openness, but not vice versa what means that productivity affects openness both in the short run and in the long run in case of Hungary. 
Table 4. The Results of VECM model estimation

\begin{tabular}{|c|c|c|c|}
\hline Item & Variable & $\begin{array}{c}\text { Equation } \\
\text { d_ln_Openess }\end{array}$ & $\begin{array}{c}\text { Equation } \\
\text { d_ln_Productivity }\end{array}$ \\
\hline \multirow{6}{*}{ UE-15 } & const & 5.081 & 0.594 \\
\hline & d_ln_Openess $(-1)$ & 0.058 & -0.060 \\
\hline & d_ln_Productivity $(-1)$ & 2.483 & 0.801 \\
\hline & ECM & -1.071 & -0.124 \\
\hline & R2 & $57 \%$ & $51 \%$ \\
\hline & DW & 2.17 & 1.69 \\
\hline \multirow{6}{*}{$\begin{array}{l}\text { Czech } \\
\text { Republic }\end{array}$} & const & 4.502 & 0.643 \\
\hline & d_ln_Openess(-1) & 0.418 & 0.137 \\
\hline & d_ln_Productivity(-1) & 0.677 & 0.456 \\
\hline & ECM & -0.953 & -0.135 \\
\hline & $\mathrm{R} 2$ & $52 \%$ & $26 \%$ \\
\hline & DW & 0.08 & 1.80 \\
\hline \multirow{6}{*}{ Hungary } & const & 1.141 & -0.002 \\
\hline & d_ln_Openess(-1) & 0.312 & -0.051 \\
\hline & d_ln_Productivity(-1) & -1.547 & 0.364 \\
\hline & ECM & -0.477 & 0.008 \\
\hline & $\mathrm{R} 2$ & $59 \%$ & $15 \%$ \\
\hline & DW & 1.83 & 2.07 \\
\hline \multirow{6}{*}{ Poland } & const & 2.640 & 0.377 \\
\hline & d_ln_Openess(-1) & 0.096 & -0.013 \\
\hline & d_ln_Productivity(-1) & -0.503 & 0.187 \\
\hline & ECM & -1.092 & -0.146 \\
\hline & R2 & $58 \%$ & $23 \%$ \\
\hline & DW & 2.26 & 1.93 \\
\hline \multirow{6}{*}{ Slovakia } & const & 2.096 & -0.132 \\
\hline & d_ln_Openess(-1) & 0.457 & 0.012 \\
\hline & d_ln_Productivity(-1) & -0.110 & 0.138 \\
\hline & ECM & -0.740 & 0.058 \\
\hline & $\mathrm{R} 2$ & $42 \%$ & $10 \%$ \\
\hline & DW & 2.24 & 1.89 \\
\hline
\end{tabular}

No restrictions on the constant term are imposed (only for UE-15 and Czech Republic the restricted trend was also imposed), basing on natural logarithms of variables.

Source: own study in JMulti 
In other cases we do not observe significant short-run relationships between variables. More specifically, the negative value of ECM parameters $\varphi$ for EU-15 (-1.071) and comparable Poland (-1.092), Czech Republic (-0.953), Hungary (-0.477) and Slovakia (-0.740) means that a wrong-way move of $\ln O$ peness is more than completely corrected by the cause of other variable $\Delta$ InProductivity ${ }_{t}$ within the next period in three first cases. In other words, a deviation of the variable Openness from its long-run equilibrium value in one period is corrected in the next period by the size of $\varphi$, which is around 107 and 109 percent respectively according to our estimates. In Slovakia and especially in Hungary the process of coming back to long-run equilibrium takes more time. In case of Productivity equations we observe moderately high level of model explanation in contrast to Openness equations, where $\mathrm{R}^{2}$ varies from $10 \%$ for Slovakia to $26 \%$ for Poland. Taking into account DW statistics and conducted autocorrelation tests, the obtained results are not affected by the problem of autocorrelation.

\section{Conclusion}

This analysis shows that variables approximating economy productivity and openness are co-integrated. This means that there is a long run relationship between these two variables. However, in the Granger sense, causality between the series is unidirectional, running from productivity to openness to trade only in case of Hungary. The short-run relation appears to be related to one period back only. The obtained estimated results have shown that Hungarian economy openness to trade is strictly related to productivity. The more productive Hungarian economy leads to the more open economy.

Using econometric methods, we reject the hypothesis stating that economy openness leads to more productive economy basing on the case of Hungary. However co-integration between time series is observed and productivity and openness cannot drift too far apart, causality in Granger sense (apart from this tool's imperfections) suggests that causality runs from productivity to openness but not vice versa. This in turn leads to further in-depth research.

Also, results presented in this study are partly consistent with the ones obtained by focused on FDI Gurgul and Lach (2009), which states that that knowledge of past dynamics of the quarterly growth of FDI in Poland allows for a better assessment of current and future rate changes openness of the Polish economy and vice versa and confirm the fairly obvious thesis on the impact of FDI on stage openness of the Polish economy and vice versa. On the other hand, openness of the economy favours and even allows FDI flows, that is one of the most important factors in improving productivity in the host country (taking into account the external spillover effects occurrence). However, FDI flows are determined by many different factors (Wach, Wojciechowski, 2014)

\section{References}

Barro, R. J. (2001). Human Capital and Growth. American Economic Review, AEA P\&P, 91(2), 12-17.

Barro, R.J., Sala-i-Martin, X. (2004). Economic Growth, (2nd ed.). New York: McGraw-Hill.

Cameron, G., Proudman, J., Redding, S. (1998). Productivity Growth in an Open Economy. Bank of England Working Paper, New College, Oxford.

Dickey, D. A., Fuller, W. A. (1979). Distribution of the Estimators for Autoregressive Time Series with a Unit Root. Journal of the American Statistical Association, 74(366), 427-431.

Edwards, S. (1998). Openness, Productivity and Growth: What Do We Really Know?. Economic Journal, 108, 383-398. 
Engle, R.F., Granger, C.W.J. (1987). Cointegration and Error Correction: Representation, Estimation and Testing. Econometrica, 55(2).

Easterly, W., Levine, R. (2001). It's not Factor Accumulation: Stylized Facts and Growth Models. The World Bank Economic Review, 15(2).

Frankel, J. and Romer D. (1999). Does Trade Cause Growth?. The American Economic Review, 89(3), 379-399.

Gonzalez, G., Constantin, S. (2009). Explaining TFP Growth Rates: Dissimilar Effect of Openness between Different Income Groups of Countries. MPRA Paper, 17584.

Granger, C.W.J. (1969). Investigating Casual Relations by Econometric Models and Cross-Spectral Methods. Econometrica, 37.

Granger, C.W.J. (1983). Co-integrated Variables and Error-Correcting Models. University of California (San Diego), Discussion Paper, 83-13a.

Gunes, S., Kose, S. (2013). Does Openness Increase Productivity? Evidence from an Emerging Economy: Turkey. International Journal of Humanities and Social Science, 3(5), 72-77.

Gurgul, H., Lach, Ł. (2009). Związki przyczynowe pomiędzy bezpośrednimi inwestycjami zagranicznymi w Polsce a podstawowymi wskaźnikami makroekonomicznymi. Ekonomia Menedżerska, 6, 77-91.

Herzer, D. (2005). Does Trade Increase Total Factor Productivity: Cointegration Evidence for Chile. Ibero America Institute for Econ. Research (IAI) Discussion Papers, 115, Ibero-America Institute for Economic Research.

Johansen, S. (1988). Statistical Analysis of Cointegration Vectors. Journal of Economic Dynamics and Control, 12.

Johansen, S., Juselius, K. (1990). Maximum Likelihood Estimation and Inference on Cointegration with Applications to the Demand for Money. Oxford Bulletin of Economics and Statistics, 52(2), 169-210.

Krugman, Paul (2013, 18 August). The New Growth Fizzle. New York Times. Retrieved from: http:// krugman.blogs.nytimes.com/2013/08/18/the-new-growth-fizzle/?_r=1

Kumar, S., Pacheco, G., Rossouw, S. (2010). How to Increase the Growth Rate in South Africa. MPRA Paper, 26105.

Kusideł, E. (2000). Modele wektorowo-autoregresyjne VAR. Metodologia i zastosowania. In: B. Suchecki (eds.), Dane panelowe i modelowanie wielowymiarowe w badaniach ekonomicznych, Łódź, Wyd. Absolwent.

Kwiatkowski, D., Phillips, P. C. B., Schmidt, P., Shin, Y. (1992). Testing the Null Hypothesis of Stationarity against the Alternative of a Unit Root. Journal of Econometrics, 54, 159-178.

Lee, D. (2007). Determinants of Chinese TFP: National and Regional Level. School of Economics, Yonsei University, Seoul, Korea.

Lucas, R.E. (1988). On the mechanics of Economic Development. Journal of Monetary Economics, 22.

Machek, O. (2012). Data Issues in Total Factor Productivity Benchmarking: A Central European Perspective. The Annals of the University of Oradea. Economic Sciences, 21(2).

Parente, S. (2001). The Failure of Endogenous Growth. Knowledge. Technology \& Policy, 13(4), 49-58. DOI:10.1007/BF02693989

Rebelo, S. (1991). Long-Run Policy Analysis and Long-Run Growth. Journal of Political Economy, 99(3), 500.

Romer, P. M. (1994). The Origins of Endogenous Growth. The Journal of Economic Perspectives, 8(1), $3-22$.

Sachs, J., Warner, D., Andrew, M. (1997). Fundamental Sources of Long-Run Growth. American Economic Review, 87(2), 184-188.

Saha, S. (2012). Productivity and Openness in Indian Economy. Journal of Applied Economics and Business Research, 2(2), 91-102. 
Tsen, W.H. (2006). Granger causality tests among openness to international trade, human capital accumulation and economic growth in China: 1952-1999. International Economic Journal, Taylor \& Francis Journals, 20(3), 285-302.

Wach, K., Wojciechowski L. (2014). The Factors of Outward FDI from V4 Countries From The Perspective of EU and EMU Membership: A Panel Gravity Model Approach. Acta Universitatis Lodziensis Folia Oeconomica, 5(307), 157-170.

Xu, H., Lai, M., Qi, P. (2008). Openness, Human Capital and Total Factor Productivity: Evidence from China. Journal of Chinese Economic and Business Studies, 63, 279-289.

Yan, I.K., Chong T.T., Kwok W.H. (2007). Openness and Productivity in China. http://cerdi.org/uploads/sfCmsContent/html/203/Chong.pdf

Yanikkaya, H. (2003). Trade Openness and Economic Growth: A Cross-Country Empirical Investigation. Journal of Development Economics, 72(1), 57-89.

Liwiusz Wojciechowski, double MA degree, $\mathrm{PhD}$ candidate, author or co-author of many scientific publications, speaker on 16 international and nationwide conferences, awarded by ERASMUS, CEEPUS, TFAS, IV\&NBP and Rector scholarships for best students, key investigator or collaborator in scientific grants. Nationwide expert in the international project Smooth Functioning of the Internal Market between V4.

\section{Adres/Address:}

Cracow University of Economics

Faculty of Economics and International Relations

Department of Entrepreneurship and Innovation

ul. Rakowicka 27

31-510 Kraków, Poland

e-mail:Liwiusz.w@o2.pl

Publikacja została sfinansowana ze środków MNiSW przyznanych Wydziałowi Zarządzania Uniwersytetu Ekonomicznego w Krakowie na badania dla młodych naukowców oraz uczestników studiów doktoranckich. 